\title{
Enhancing Internal Operational Capabilities: Interplaying Top Management Commitment and Leadership Agility Development
}

\author{
MUHAMMAD ZULKIFLI ${ }^{1}$, FIRMANZAH ${ }^{2}$, RHENALD KASALI ${ }^{3}$, TENGKU EZNI BALQIAH ${ }^{4}$, \\ MOHAMMAD HAMSAL ${ }^{5}$ \\ ${ }^{1}$ Graduate School of Management, Department of Management, Faculty of Economics and Business, \\ UNIVERSITY OF INDONESIA, INDONESIA. E-mail: mzulkifli2002@gmail.com \\ ${ }^{2}$ Graduate School of Management, Department of Management, Faculty of Economics and Business, \\ UNIVERSITY OF INDONESIA, INDONESIA. E-mail: firmanzah.d@ui.ac.id \\ ${ }^{3}$ Graduate School of Management, Department of Management, Faculty of Economics and Business, \\ UNIVERSITY OF INDONESIA, INDONESIA. E-mail: rhenald.kasali@ui.ac.id \\ ${ }^{4}$ Graduate School of Management, Department of Management, Faculty of Economics and Business, \\ UNIVERSITY OF INDONESIA, INDONESIA. E-mail: tengku.ezni@ui.ac.id \\ ${ }^{5}$ Doctor of Research in Management, Department of Management, BINUS Business School, BINA NUSANTARA \\ UNIVERSITY, INDONESIA. E-mail: mhamsal@binus.edu
}

\begin{abstract}
This paper aims to investigate the relationship between top management team (TMT) commitment and leadership development on agile leaders as part of enhancing the operational capabilities of the upstream oil and gas sector. This study adopted a quantitative method with a total of 175 participants from national and international oil companies in Indonesia. Based on the structural equation modelling analysis, the research indicates that leadership agility development has a significant impact on agile leaders, and it has a key role in operational capabilities. TMT commitment has an insignificant impact on agile leaders. Future studies should examine the other consequences of the insignificant variables.
\end{abstract}

Keywords: TMT commitment, leadership agility development, field agile leader, internal operational capabilities JEL Classification: L20, M12 


\section{Introduction}

The business of oil and gas experiences many challenges, has a high complexity, and consistently operates with a degree of uncertainty. At the same time, the oil and gas business has to engage in more competitive actions in the sector as the price instability is a significant challenge (Regnier 2007). In Indonesia oil and gas industry, the business unit performance determined by drilling activities, projects, and operational in the fields where the critical factors related to leadership in development in enhance operational capabilities that are influenced by integrating, building, and reconfiguring the company resources which is positively related to performance improvements over time (Teece et al. 1997).

Therefore, to respond to the field environment's complex and dynamic needs more concrete concepts to overcome strategic management and leadership. Strategic planning conducted in the head office by the top management that is then carried out in the field is focused on coordination, integrated capabilities, and the resources provided by the field leader. This can horizontally and directly influence flexibility (Crittenden and Crittenden 2000). Vertically, the field leadership will reduce the risk of job obstacles due to the conditions. Uncertain conditions can eventually be solved and performance increases (Nidumolu 1996).

Unfortunately most of the studies only focus on the efficient and effective operations, creativity and innovation (Sadq et al., 2019), the internal and external mechanisms (Prim et al., 2019) when enhancing the level of competitive capabilities. In another study, the top management commitment realized the importance of human capital and increased the organizational capabilities (Kaaria et al., 2018). However, there has been little empirical evidence of the specific human capital development that would support the leadership agility development.

The concept of this research model is to explore how a middle-level leader applies their managerial ability in the field amid complex and dynamic environmental perspectives. An agile organization is focused on developing and exploring via a causal model when the organization operates in a relatively unstable environment (Thao 2012). An organization could become agile by improving the individual competence in the organization (Stekelenburg 2012). This research is a continuation of the research by (Dutton et al., 2001, O'Brien 2012) on leadership capability development that integrates various capabilities and how the role of a field agile leader can influence field activities. This study is a conceptualization of agility development that influences the top management's commitment given the big impact of improving the internal operational capabilities. In other words, this understanding will explain how a field agile leader can successfully build their superiority and competence, especially in an operational area that involves rather challenging cultural differences.

\section{Literature Review}

\subsection{TMT Commitment, Leadership Agility Development and Field Agile Leader}

The top management team (TMT) commitment is defined as all leaders at or above vice president level (Michael and Hambrick 1992, Hambrick and D'Aveni 1992, Virany et al., 1992) where, typically, it is equivalent to the top two layers of an organization's hierarchy. The corporate top management is influenced by the interests of the corporation when allocating resources depending on organizational commitment (Hunt et al., 1989), including the organizational support felt (Organizational Support Theory) (Eisenberger et al., 1986, Rhoades and Eisenberger 2002). Leadership agility development is described as the policy or programs involved in developing the leadership agility in a manner that can improve the resilience and agility capacity through strategic human resource development programs. It also refers to the creation of core employee competencies consisting of three dimensions, including cognitive, behavioural and contextual development (Lengnick-Hall and Beck 2011, Chatman et al., 2005). A field agile leader is defined as a leader in the oil and gas fields, who are characterized by their leadership agility and the dynamic capacity to innovate, adapt to change, and create a new opportunity that is beneficial for the organization in an environmental of external uncertainty (Sharifi and Zhang 
1999). They also have the agile characteristics of sensitivity, flexibility, and speed (Doz and Kosonen 2010).

The top management team commitment in the top levels of leadership development is shown by the involvement and support of the top management when conducting a leadership activity (Shah 1996). The commitment of the top management encourages the success of any strategic plans (Hambrick et al., 1993, Marx 1995, Shah 1996, Ng and Wyrick 2001, Aragon-Correa et al., 2004) to improve their leadership performance in the field (Prabhu and Robson 2000). The corporate top management is influenced by the interests of the corporation. When allocating resources, this depends on the organizational commitment (Hunt et al., 1989), including the organizational support felt (Organizational Support Theory) (Eisenberger et al., 1986, Rhoades and Eisenberger 2002). TMT can also influence the human resource management in companies that are developing greater agility through action learning programs with small groups that work together on projects. These groups can provide feedback and knowledge sharing related to individual leadership improvements (Dotlich and Noel 1998, Raelin 1999). The top management team must have a clear commitment to developing the prospective company leaders by transforming and exploiting any new knowledge for the purpose of the company's strategic goals going forward (Zahra and George 2002), including increasing the capacity of the agility as the initial capital of prospective leaders.

When developing agility leadership, the human resources program should not only focus on improving the technical competence and hard skills. It should also strive to strengthen any nontechnical competencies and soft skills. In the managerial capability dynamic concept, managerial human capital refers to improving the skills, competence, and knowledge that must be possessed by every leader (Adner et al., 2003). Sirmon and Hitt (2009) highlighted how leaders are identified, recruited, organized, and even manage to achieve harmony as a company strategy when facing environmental changes. To meet this goal, the development of the leadership agility in a company is used to manage the human resources to support reaching the company's strategic objectives.

According to Lengnick-Hall et al. (2011), there are several dimensions of capacity in resilient agility, including cognitive, behavioural, and contextual. The program for developing the leaders with the cognitive abilities possessed by a leader can contribute to their agility and resilience, including collaborating with various functions through different skills that allow for their core values to develop amid the uncertainty of the crisis. The program developed by HR is intended to generate a leader through behavioural leadership. Leaders must be able to practice repeating conditions that can provide a quick response to unexpected risks. They need to be ready to take action quickly to ensure that the organization can benefit from emerging situations. This includes the courage to try new things, to learn lessons after they happen, and flexibility. HR policies and programs for the contextual dimension can result in leaders who develop personal connections within the supply lines of resources that can act quickly. Broadly, information and knowledge sharing includes (a) partnering with employees, teams and networks, (b) user-friendly, accessible and integrated information, (c) empowerment, (d) results-based assessments and (e) open communication.

$H_{1}$ : TMT Commitment has a positive effect on Leadership Agility Development

$\mathrm{H}_{2}$ : TMT Commitment has a positive effect on Field Agile Leaders

\subsection{Field Agile Leader and Internal Operational Capabilities}

Internal operational capabilities are defined as the integration of a series of complex internal activities carried out by a company to increase its output through the most efficient use of production capabilities, technology, and business process flows (Hayes et al., 1988). The type of internal capabilities are operationalized in to the business process governance (Hayes et al., 1988) to improve efficiency by reducing operational risk and costs, reaching a competitive advantage (Day 1994), team capability in managing the team, including an ability to give clear roles and responsibilities, regular communication between managers to team and also vendor, including the communication methods (Erickson and Ranganathan 2006), and planning, control, and evaluation (Erickson and Ranganathan 
2006) to ensure the plans with estimate and allocate resources, performance monitoring, and corrective actions mitigation.

Internal operational capabilities will improve efficiency by reducing the operational risk and costs, thus reaching a competitive advantage (Day 1994). Operations capabilities include indicators such as the effectiveness of the competitive responsiveness, competency, flexibility, speed (Zang and Sharifi 2000 ), the execution of activities to ensure the continuation of competitive capabilities and performance, productivity, time, flexibility, and quality (De Toni and Tonchia 2001). These can be expanded to govern to the business process and team capabilities, including planning, control, and evaluation.

Core capabilities understand the need to provide the necessary combination of 'speed and stability' to form agility for use by the organization. Having vision and clarity makes the aforementioned easier to execute, as all of the value chain partners are in sync and have a desire to take advantage of particular opportunities that may surface (Long 2000).

A leader who uses agile leadership can see networks, listen to others, tune in their style of control, be focused under pressure, and are willing to make the necessary sacrifices for perfect results. Long (2000) delivered a measurement of agility, consisting of six dimensions. These were clarity as visionary, core capabilities, understanding the stakeholders' knowledge, selecting strategic targets, target alignment, responsibility, the familiarity of their competitors, and action orientation. Firmanzah (2013), in their study on working relationships, stated that the role of clarity is vital for subsidiary managers (field leaders) because they need the functional clarity, clear tasks, and jobs when interacting with headquarters. The ability to choose specific targets lets a company make changes and enhance or develop their current and future opportunities.

Another significant part of the strategic agility as proposed by Sambamurthy et al. (2003) is action orientation. This shows the extent to which the company can take immediate action as various opportunities become apparent. In other words, this shows how quickly an organization's leader can respond. According to Doz and Kosonen (2010), benefits and alignment are the most apparent mechanisms. However, one that is often understood as being a small problem only. Doz and Kosonen (2010) also proposed that resources fluidity is a component of agility leadership. Even when in possession of resources that has more impact, even a deeply felt commitment at the top does not always translate into thriving and vibrant action. A variety of leadership actions can help in any situation. Yousif et al. (2016) explained agility leadership as a model involving the leadership's commitment to innovation, change, and the dynamics that are able to operate effectively in a hypercompetitive environment. These dynamics cannot be predicted and are continuously changing. Agility can be limited according to the organizational ability to feel environmental changes and respond efficiently and effectively (Ashrafi et al., 2005).

In the assumption that dynamic ability theory is a standard framework (Teece et al., 1997), agility is one of the key dynamic abilities used by an organization to achieve a competitive advantage (Sambamurthy et al., 2003). It is also the ability to survive in a volatile environment (Nijssen and Paauwe 2012). Many companies consider agility to be essential when ensuring a business leaders' sustainability and those of competitive advantages (Lin et al., 2006, Sharifi and Zhang 1999). Having this ability can be useful when facing quick changes, maintaining sustainability, and seizing new opportunities. According to Shah (1996), one of the factors that determine leadership success in the context of project implementation is the commitment of the top management. The strategy implementation and programs of the top management require field agile leaders to enhance the operational capabilities. This is by taking effective actions when facing new situations that are full of challenges (Bryson 1988).

Field leaders will implement the strategic plans of the top management to help the company control any changes and to construct project scenarios to achieve success (Asrilhant et al., 2006, Godet 2000). Grant (2003), in a study on large oil and gas companies, found that strategic planning is used to make strategic decisions and that there are coordinated and controlled mechanisms to respond to 
dynamic environmental conditions. When agility is strategically directed, it changes the management (Teece et al., 2016). Improving competence is a skill that permits a company to use knowledge appropriately. Agility is a dynamic ability that originates from a knowledge-generating strategy and it assists organizations in getting a much better deal as a result of handling change (Sambamurthy et al., 2003), a necessary skill for field leaders. Long (2000) depicted the strategic agility dimension as a certain clarity of vision, a shared responsibility, the ability to understand core capabilities, the skill to take action, and the capability to select strategic targets. An organization's simplicity of vision and understanding of its capabilities is needed, in addition to the ability to make quick decisions and to find stability in strategic agility. If an organization does not understand its core capabilities, it will not be able to take advantage of other aspects (Long 2000).

H3: Leadership Agility Development has a positive effect on Field Agile Leaders

H4: Field Agile Leaders have a positive effect on the Internal Operational Capabilities

Figure 1 Research Model

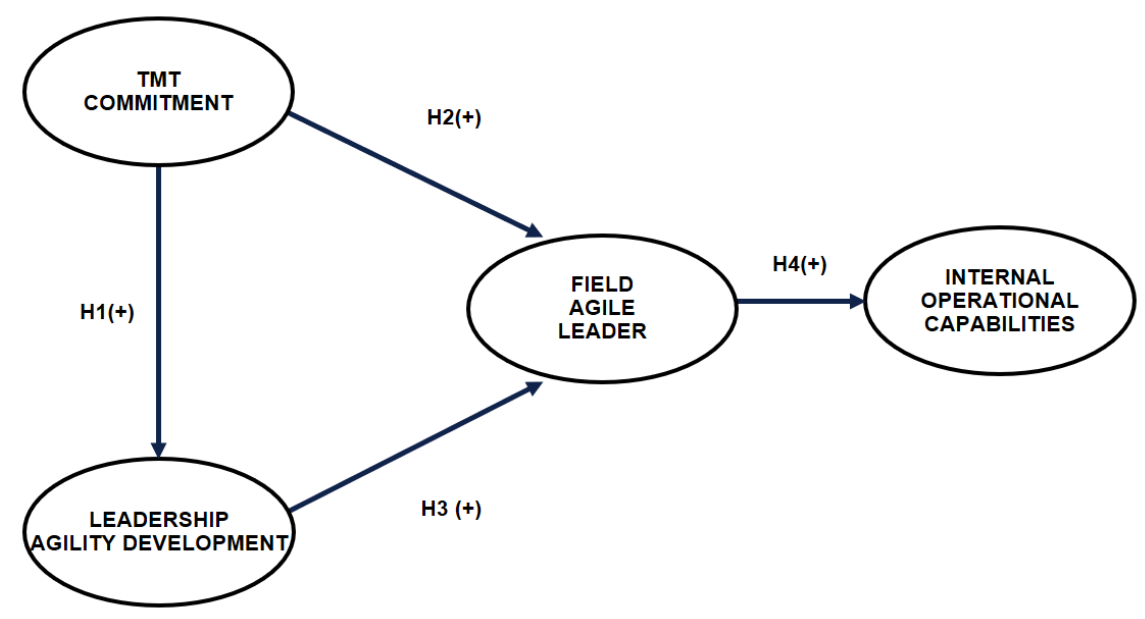

\section{Methodology}

The data collection in this study was performed by sending a questionnaire to the respondents about the respondents' opinion on related topics. This data involved middle-level managers who serve as field leaders (operations managers, drilling managers, and project managers). Lastly, evidence was collected through supporting documents drawn from a comprehensive literature review, in addition to databases and the specific linkages found between the content of the case study protocol and the research questions. The data collection produced samples of research data that were processed and analysed further. The data collected through the data collection technique became the sample data. The collected sample data was then analysed using two methods, i.e. descriptive analysis and analysis measurements using structural equation modelling (SEM).

This form of analysis describes the profile of the units of the study (field units) which are part of the research sample, in addition to the persons who answer the questionnaire's statements. SEM analysis is described as a statistical technique used to test, specify, and estimate the causal connections among the variables, where the variables are latent. A latent variable (LV) is a variable that cannot be calculated or directly observed but instead seen through other indicators, namely the measured/observed variables (MVs/OVs). There are causal relationships between the research variables, i.e. TMT commitment, leadership agility development (LAD), field agile leader (FAL) and internal capabilities (IOC). Part of SEM shows the causal relationships among the LVs, known as the structural model, whereas part of SEM shows the relationships between an LV and its indicators/MVs/OVs using the measurement model. This is frequently called Confirmatory Factor Analysis (CFA). 
Table 1 Research variables, dimensions, and indicator codes

\begin{tabular}{|c|c|c|c|}
\hline Variables & Dimensions & Number of Indicators & References \\
\hline \multirow{3}{*}{$\begin{array}{c}\text { TMT } \\
\text { Commitment }\end{array}$} & Internal Commitment & 8 (TMCIN1-TMCIN8) & \multirow{3}{*}{$\begin{array}{l}\text { Fattouh and Darbouche } 2010, \\
\text { Acha and Finch 2005, Haque 2004, } \\
\text { Chowdury et al., 2007, Shah } 1996 .\end{array}$} \\
\hline & Working Environment & 6 (TMCWE1-TMCWE8) & \\
\hline & External Environment & 7 (TMCEX1-TMCEX7) & \\
\hline \multirow{3}{*}{$\begin{array}{c}\text { Leadership } \\
\text { Agility } \\
\text { Development }\end{array}$} & Cognitive Development & 7 (LADCG1-LADCG7) & \multirow{3}{*}{$\begin{array}{c}\text { Lengnick-Hall et al., 2011, Chatman } \\
\text { and Flynn } 2005 .\end{array}$} \\
\hline & Behavior Development & 7 (LADBV1-LADBV7) & \\
\hline & Contextual Development & 7 (LADCT1-LADCT7) & \\
\hline \multirow{3}{*}{$\begin{array}{l}\text { Field Agile } \\
\text { Leader }\end{array}$} & Sensitivity & 6 (FALSE1-FALSE6) & \multirow{3}{*}{$\begin{array}{c}\text { Sharifi and Zhang 1999, } \\
\text { Sambamurthy et al., 2003, Teece et } \\
\text { al., 1997, Zott 2003. }\end{array}$} \\
\hline & Flexibility & 6 (FALFL1-FALFL6) & \\
\hline & Speed & 6 (FALSP1-FALSP6) & \\
\hline \multirow{3}{*}{$\begin{array}{l}\text { Internal } \\
\text { Operational } \\
\text { Capability }\end{array}$} & $\begin{array}{c}\text { Capability to Govern the } \\
\text { Business Process }\end{array}$ & 5 (IOCBP1-IOCBP5) & \multirow{3}{*}{$\begin{array}{l}\text { Jugdev et al., 2007, Keegan and } \\
\text { Turner 2002, Soderlund 2004, Zott } \\
2003 .\end{array}$} \\
\hline & Team Capability & 7 (IOCTC1-IOCTC7) & \\
\hline & $\begin{array}{l}\text { Capability to Plan, } \\
\text { Control \& Evaluation }\end{array}$ & 7 (IOCPC1-IOCTC7) & \\
\hline
\end{tabular}

This study adopted a systematic probability technique with the respondents from the oil and gas sector fields. The respondents were selected based on several specific related profiles, such as that of an Operations Manager, Project Manager, Drilling Manager or Superintendent. The sample was selected from a populace with particular standards. The primary data of this study was collected using online surveys in the form of structured questionnaires. The duration of the data collection was three months from November 2019 to January 2020. As a result, 175 respondents had their data gathered through an online questionnaire. The maximum likelihood sampling was accepted with a range of 50 - 100 respondents (Hair et al., 2010) to achieve SEM's numerical requirements. Figure 1 shows the research model, which consists of 5 research variables: TMT commitment, leadership agility development (LAD), field agile leader (FAL) and internal capabilities (IOC). The research variables were expanded further by adding measurement dimensions as well as indicators. The definitions of the research variables and their dimensions have been listed in Table 1.

\section{Result and Discussion}

\subsection{Profile of Respondents}

The data was analysed using SEM and the total sample size was 175 . One of the main reasons for using SEM is that it is an appropriate and efficient approximation techniques to use in relation to a series of separate multi-regression equations estimated concurrently (Hair et al., 2013). The variables in the research model as LVs cannot be calculated directly. Instead, they can only be calculated through indicators or the observed variables. This is known as model of measurement I in SEM. The other reason is that the relationships among the LVs are quite complex, in terms of being in the form of simultaneous equations. This is known as a structural model in SEM (Hair et al., 2013). SEM also depicts the associations among the observed variables and LVs in many theoretical models which deliver a quantitative test in relation to the hypotheses. This procedure includes the measurement model analysis followed by the structural model analysis. The target population were national oil companies (NOCs) and international oil companies (IOCs) in Indonesia, so long as they were a legal business entity. The respondent's profile and the characteristics of the oil and gas sector in this survey have been presented in Table 2.

Table 2 Demographic characteristics of the respondents

\begin{tabular}{|c|c|c|c|}
\hline No. & Characteristics & Frequency & Percentage (\%) \\
\hline 1. & Age of the respondents & 8 & 5 \\
\hline & $25-35$ years & 85 & 49 \\
\hline & $36-45$ years & 82 & 47 \\
\hline & $>46$ years & & 96 \\
\hline 2. & Gender of the respondents & 168 & 4 \\
\hline & Male & 7 & 2 \\
\hline 3. & Female & 3 & \\
\hline & Highest qualification of the respondents & & \\
\hline
\end{tabular}




\begin{tabular}{|c|c|c|c|}
\hline & Natural Science & 9 & 5 \\
\hline & Social Science & 7 & 4 \\
\hline & Engineering & 156 & 89 \\
\hline \multirow[t]{5}{*}{4.} & Level of education & & \\
\hline & High School & 4 & 2 \\
\hline & Diploma & 7 & 4 \\
\hline & Bachelor's & 91 & 52 \\
\hline & Master's/Doctoral & 73 & 42 \\
\hline \multirow[t]{4}{*}{5.} & Position of the respondents & & \\
\hline & Drilling Manager/Superintendent & 113 & 65 \\
\hline & Operations Manager & 30 & 17 \\
\hline & Project Manager & 32 & 18 \\
\hline \multirow[t]{4}{*}{6.} & Experience of the respondents & & \\
\hline & $<5$ years & 7 & 4 \\
\hline & $5-10$ years & 14 & 8 \\
\hline & $>10$ years & 154 & 88 \\
\hline \multirow[t]{3}{*}{7.} & Company type & & \\
\hline & National Oil Companies (NOCs) & 124 & 71 \\
\hline & International Oil Companies (IOCs) & 51 & 29 \\
\hline \multirow[t]{4}{*}{8.} & Budget authority & & \\
\hline & $<\$ 1,000,000$ & 100 & 57 \\
\hline & $\$ 1,000,000-5,000,000$ & 30 & 17 \\
\hline & $>\$ 5,000,000$ & 45 & 26 \\
\hline
\end{tabular}

\subsection{Measurement and Structural Model}

The measurement model analysis aimed to evaluate the validity and reliability of the measurement model. Figure 1 and Table 1 show the measurement models of the research variables including LAD, FAL, IOC, and TMC. The models of measurement are second-order models or 2 nd Order CFAs. Each 2nd Order CFA consists of first-order measurement models representing the relationship between a dimension and its indicators (1st Order CFA), and second-order measurement models, representing the relationship between a research variable and its dimensions. An assessment of the validity of the indicators in their dimensions (1st Order CFA) was executed by analysing the indicators' standardized factor loading (SFL). If the SFL of an indicator is $\geq 0.50$, the indicator is regarded as valid. If the SFL is $<0.50$, then the indicator is not valid and it is excluded or dropped from the measurement model. The results show that the indicators in Table 1 had an SFL higher than 0.50 , thus they were all found to be valid indicators/measurements of their stated dimensions. A similar procedure was applied to evaluate the validity of the dimensions for the related research variables. The results show that all dimensions were valid measurements of their associated variables. An evaluation of the reliability of the measurement model of the dimensions (1st Order CFA) and research variables (2nd Order CFA) was executed by testing the variance extracted (VE) and construct reliability (CR). All measurement models of the dimensions had a $C R \geq 0.70$, whereas some had a VE slightly $<0.50$. However, in general, the dimensions had good reliability.

Table 3 Measurement Model Assessment Using CFA

\begin{tabular}{|c|c|c|c|c|c|c|}
\hline Variable & SFL $\geq 0.5$ & Error & CR $\geq 0.7$ & VE $\geq 0.5$ & RMSEA $\leq 0.08$ & GFI $\geq 0.9$ \\
\hline \multicolumn{7}{|c|}{ Field Agile Leader } \\
\hline Sensitivity & 0.92 & 0.15 & 0.94 & 0.85 & 0.075 & 0.92 \\
\hline Flexibility & 0.89 & 0.20 & 0.94 & 0.85 & 0.075 & 0.92 \\
\hline Speed & 0.94 & 0.11 & 0.94 & 0.85 & 0.075 & 0.92 \\
\hline \multicolumn{7}{|c|}{ Internal Operational Capabilities } \\
\hline $\begin{array}{c}\text { Govern Business } \\
\text { Process }\end{array}$ & 0.78 & 0.40 & 0.91 & 0.77 & 0.075 & 0.92 \\
\hline Team Capability & 0.94 & 0.11 & 0.91 & 0.77 & 0.075 & 0.92 \\
\hline $\begin{array}{c}\text { Plan, Control \& } \\
\text { Evaluate }\end{array}$ & 0.90 & 0.19 & 0.91 & 0.77 & 0.075 & 0.92 \\
\hline \multicolumn{7}{|c|}{ Leadership Agility Development } \\
\hline Cognitive & 0.92 & 0.15 & 0.83 & 0.56 & 0.075 & 0.92 \\
\hline Behavioral & 0.90 & 0.18 & 0.83 & 0.56 & 0.075 & 0.92 \\
\hline Contextual & 0.55 & 0.70 & 0.83 & 0.56 & 0.075 & 0.92 \\
\hline
\end{tabular}




\begin{tabular}{|c|c|c|c|c|c|c|}
\hline \multicolumn{7}{|c|}{ TMT Commitment } \\
\hline Internal Commitment & 0.84 & 0.29 & 0.86 & 0.68 & 0.075 & 0.92 \\
\hline Working Environment & 0.85 & 0.25 & 0.86 & 0.68 & 0.075 & 0.92 \\
\hline External Commitment & 0.76 & 0.41 & 0.86 & 0.68 & 0.075 & 0.92 \\
\hline
\end{tabular}

Meanwhile, all five measurement models of the research variables had a $V E \geq 0.50$ and $C R \geq 0.70$. This means that all research variables had good reliability. It can be concluded that the measurement models of the research variables have good validity and reliability. By having LS, the indicators should be simplified, becoming one compacted indicator. By referring to the research model in Figure 1, the minimum sample size required for this research was established as needing to be $5 \times 12=60$ managers. The sample size of this research was 175, meeting the requirement.

Table 4 Summary of the estimation results and overall model fit

\begin{tabular}{|c|c|c|c|}
\hline Path & Coefficient & t-value $^{*}$ & Conclusion $^{*}$ \\
\hline TMC $\geq$ LAD & 0.91 & 12.07 & Significant Positive \\
\hline TMC $\geq$ FAL & -0.28 & -1.37 & Not Significant \\
\hline LAD $\geq$ FAL & 1.13 & 5.43 & Significant Positive \\
\hline FAL $\geq$ IOC & 0.86 & 11.30 & Significant Positive \\
\hline
\end{tabular}

GOFI: RMSEA $\left(\leq 0.08^{* *}\right)=0.065 ;$ CFI $\left(\geq 0.90^{* *}\right)=0.99 ;$ IFI $\left(\geq 0.90^{* *}\right)=0.99 ; \mathrm{NFI}\left(\geq 0.90^{* *}\right)=0.98$

The second step was to analyse the structural model. It aimed to investigate the relationships among the latent variables of the research that form the hypotheses. The analysis consisted of the overall model fit analysis and a significance test to determine the path coefficient. The measurement model analysis caused the transformation of the measurement models of four research variables from 2nd Order CFA to 1st Order CFA. The results were used to simplify the model of the research in Figure 2.

Figure 2 Overall model fit

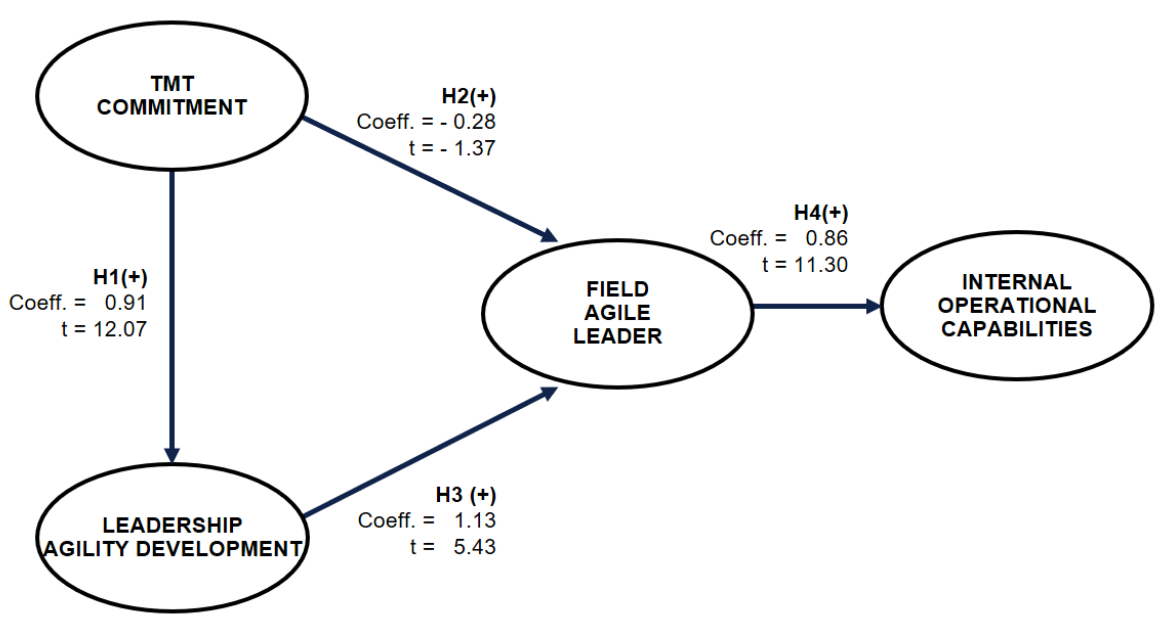

The estimation results and overall model fit have been summarized in Table 2. Table 2 also indicates that all GOFIs (RMSEA, NNFI, CFI, IFI, and GFI) have a good fit. It can be concluded that the overall model fit is right. The hypotheses of the research were tested, and the results are presented in Table 3. The data supports only three out of four hypotheses. As shown in Table 3, the coefficients of LAD were 1.13 for FAL. The coefficient of TMC to LAD and FAL were 0.91 and -0.28 respectively. Meanwhile, the coefficient was 0.86 for FAL to IOC. The simplified research model was significantly affected when the $t$-value was more than 1.96, except for TMC to FAL, which was -1.37 respectively. This signifies an insignificant relationship between the variables.

In summary, Table 4 describes that three of four hypotheses are supported. $\mathrm{H} 1, \mathrm{H} 3$, and $\mathrm{H} 4$ have significant positive results while $\mathrm{H} 2$ is insignificant. The research findings confirm that TMT commitment is considered to be a determining factor when developing leadership agility development which is aligned with the work of (Zahra and George 2002). This work also states that TMT is committed to building a leader through transformation and exploiting new knowledge while also building the 
leadership capacity for resilience. Agility is needed within an organization to act and effectively reconfigure the resources in the current circumstances.

Table 5 Test Results of the Research Hypotheses

\begin{tabular}{|c|c|c|c|}
\hline \multicolumn{2}{|r|}{ Hypotheses of Research } & Results & Conclusion \\
\hline $\mathrm{H}_{1}$ & $\begin{array}{c}\text { TMT Commitment has a positive effect on Leadership Agility } \\
\text { Development }\end{array}$ & Significant Positive & H1 Supported \\
\hline $\mathrm{H}_{2}$ & TMT Commitment has a positive effect on Field Agile Leader & Not Significant & H2 Not Supported \\
\hline $\mathrm{H}_{3}$ & $\begin{array}{l}\begin{array}{l}\text { Leadership Agility Development has a positive effect on Field Agile } \\
\text { Leader }\end{array} \\
\end{array}$ & Significant Positive & H3 Supported \\
\hline $\mathrm{H}_{4}$ & $\begin{array}{l}\text { Field Agile Leader has a positive effect on the Internal Operational } \\
\text { Capabilities }\end{array}$ & Significant Positive & H4 Supported \\
\hline
\end{tabular}

In (H3), the agility development of the leadership is the most influential antecedent of a field agile leader which is in line with the extant articles that support the importance of leadership agility development. Lengnick-Hall et al. (2011) explained that policies and programs to progress the leadership capacity with the characteristics of cognitive, behavioral, and contextual development for the leader need to be more resilient and agile through strategic human resource management. The improvement of the capacity for resilience agility in the workforce and leaders as the front line when shaping the unit performance has stimulated the corporation to develop a varied repertoire of resources. Only flexible, agile, and endlessly dynamic organizations will thrive in a complex, uncertain, and threatening environment.

This research also confirms that field agile leader positively affect the internal operational capability $(\mathrm{H} 4)$ that supports the concept of agility and dynamic capability that enables firms to modify their operational routines to cope with the changing external environment (Sambamurthy et al., 2003, Teece et al., 1997). With the assumption that dynamic ability theory is a reference structure (Teece et al., 1997), agility is one of the key dynamic capabilities that an organization can use to reach sustainable competitive superiority (Sambamurthy et al., 2003) and survive in a volatile environment (Nijssen and Paauwe 2012). Agile leaders can continually adapt to multifaceted, unpredictable, dynamic and uncertain environments (Shafer 1997). Many companies consider agility to be essential for business leaders to ensure their sustainability and competitive advantages (Sharifi and Zhang 1999, Lin et al., 2006). This ability can be useful when facing quick changes, maintaining sustainability, and engaging with new opportunities. Operational capabilities, including the processes, technology, excellence and the quality of the company's operations involved, can bring about a competitive advantage (Dutta et al., 1999, Lieberman and Dhawan 2005, Narasimhan et al., 2006).

This study found that TMT commitment actually has no direct effect on field agile leaders. TMT commitment is not considered to be a determining factor of field agile leader. These finding are opposite to the statement indicating that the commitment of the top management will assist the field leaders in maintaining long-term efficiency and effectiveness (Van der Vegt et al., 2015). According to Miller and Pazgal (2002), through a commitment of the management, especially the top management, operational projects and drilling can be carried out effectively to fulfill the stakeholders' targets, including increasing the company profit. It is not easy to do this because the commitment must be real, consistent and seen at every level (Sakthivel 2007).

The upstream oil and gas industry in Indonesia is quite complicated, mixing technical, business, political, and social factors primarily when interacting with the local government, local authorities, and local community in the field. It requires a strong leader to manage this kind of situation in the field. Therefore, only agile leaders in the field can handle the situation on a daily basis. It is feasible that the leaders in the field have the perception that the top management does not directly help them with the day-to-day operations. From this perspective, this result is not surprising as the middle-level managers have no directly interaction with the top management in the headquarters. The interaction between the top management and the managers in the field are only through regular messages via emails or 
town hall meetings on a quarterly basis. The field managers experience no direct impact on their routine activities, with a potential for future research.

\section{Conclusions, Limitations and Recommendations for Further Research}

This research contributes to understanding the impact of an agile leader and explaining how the agile leader developed in enhances operational capabilities. This research has also clarified the relationship of resources base theory and upper echelon theory in continuing the importance of the resources. This research also contributes the comprehensive framework that was used to answer the challenges associated with robustness, a broader scope, and a multilevel more dynamic model of leadership agility development.

This research indicates important of leadership agility development in developing agile leaders to enhance operational capabilities which could lead to capabilities in various contexts, which is applied in strategic management. In addition, this study also addressed team capabilities, governance, planning, control, and evaluation. This research confirms the relationship between TMT commitments, leadership agility development to develop agile leader in order to enhance internal operational capabilities

Detailing the operational capabilities concept as it develops will enrich the agility in capabilities in various contexts, which is applied in strategic management. This study contributes to the empirical research based on the resource base theory related to team capabilities, governance, planning, control, and evaluation. Through a resource-based perspective in strategic management, this study identifies the relationship between TMT commitment and the leadership's agility development, including how it is used to enhance the internal operational capabilities.

This study has several limitations. First, this study used a cross-sectional design. Therefore, it is better to conduct longitudinal research in the future to gain a more in-depth insight into the dynamics of the oil and gas business. Second, most of the respondents in this study came from the upstream oil and gas business. This affects more than $80 \%$ of Indonesia's gross domestic product (GDP). It is recommended that future research should be carried out covering other middle and downstream sectors that could have a more significant impact on oil and gas development. Third, the context of this empirical study is too limited to certain areas. It is recommended that future research is carried out by expanding into other energy sectors such as electrical power and renewable energy which have a more significant impact on the country.

Furthermore, this study shows the process through which top management commitment at the company level will impact on the ground. This study also contributes to the internal measurement of operational capabilities in the context of field operations in the oil and gas sector. Since the upstream oil and gas industry in Indonesia is quite complicated, mixing among technical, planning and govern to process in the fields, it has required agile leader who has capabilities to manage various challenges of situation in order to improve oil or gas production in most efficient and effective ways.

\section{Acknowledgement}

This research work was supported by the Project of International Publication on Doctoral Student Index (PITMA A), University of Indonesia.

\section{References}

1. Acha, V. L. And Finch, J. (2005). "Paths to deepwater in the international upstream petroleum industry". Technology, Knowledge and the Firm: Implications for Strategy and Industrial Change, Edward Elgar, Cheltenham, 73-91.

2. Adner, R. And Helfat, C. E. (2003). "Corporate effects and dynamic managerial capabilities". Strategic Management journal, 24(10), pp. 1011-1025. 
3. Aragon-Correa, J. A., Matias-Reche, F., \& Senise-Barrio, M. E. (2004). Managerial discretion and corporate commitment to the natural environment. Journal of Business research, 57(9), 964-975.

4. Ashrafi, N.; Xu, P.; Sathasivam, M.; Kuilboer, J. P.; Koelher, W.; Heimann, D. and Waage, F. (2005). "A framework for implementing business agility through knowledge management systems". In Seventh IEEE International Conference on E-Commerce Technology Workshops (pp. 116-121). IEEE.

5. Asrilhant, B.; Meadows, M. and Dyson, R. (2006). "Techniques to support successful strategic project management in the UK upstream oil and gas sector". European Management Journal, 24(23), pp. 214-225.

6. Bryson, J. M. (1988). "A strategic planning process for public and non-profit organizations". Long range planning, 21(1), pp. 73-81.

7. Chatman, J. A. and Flynn, F. J. (2005). "Full-cycle micro-organizational behavior research". Organization Science, 16(4), pp. 434-447.

8. Crittenden, W. F. And Crittenden, V. L. (2000). "Relationships between organizational characteristics and strategic planning processes in nonprofit organizations". Journal of Managerial Issues, 12(2), pp. 150-168.

9. Day, G. S. (1994). "The capabilities of market-driven organizations". Journal of Marketing, 58(4), pp. 37-52.

10.Dotlich, D. L. And Noel, J. L. (1998). "Action learning: How the world's top companies are re-creating their leaders and themselves". Jossey-Bass Publishers: California.

11.Doz, Y. L. And Kosonen, M. (2010). "Embedding strategic agility: A leadership agenda for accelerating business model renewal". Long range planning, 43(2-3), pp. 370-382.

12.Dutta, S.; Narasimhan, O. and Rajiv, S. (1999). "Success in high-technology markets: Is marketing capability critical?". Marketing Science, 18(4), pp. 547-568.

13.Dutton, J. E.; Ashford, S. J.; O'neill, R. M. and Lawrence, K. A. (2001). "Moves that matter: Issue selling and organizational change". Academy of Management journal, 44(4), pp. 716-736.

14.Eisenberger, R., Huntington, R., Hutschison, S. and Sowa, D. (1986). "Perceived organizational support". Journal of Applied psychology, 71(3), pp. 500-507.

15.Erickson, J. M. and Ranganathan, C. (2006, January). "Project management capabilities: Key to application development offshore outsourcing". In Proceedings of the 39th Annual Hawaii International Conference on System Sciences (HICSS'06) (Vol. 8, pp. 199b-199b). IEEE.

16.Firmanzah, F. (2013). "The Effect of Headquarter Integration Mechanisms on Subsidiaries' New Product Success: From Control to Coordination Mechanism". The South East Asian Journal of Management, 1(2), pp. 191-212.

17.Godet, M. (2000). "The art of scenarios and strategic planning: tools and pitfalls". Technological forecasting and social change, 65(1), pp. 3-22.

18.Grant, R. M. (2003). "Strategic planning in a turbulent environment: Evidence from the oil majors". Strategic management journal, 24(6), pp. 491-517.

19.Hair, J. F.; Joseph, F.; Black, W. C.; Babin, B. J. and Anderson, R. E, (2010). Multivariate data analysis. Library of Congress Cataloging-in-Publication Data.

20.Hair, J. F.; Ringle, C. M. and Sarstedt, M. (2013). "Partial least squares structural equation modeling: Rigorous applications, better results and higher acceptance". Long range planning, 46(1-2), pp. 112.

21.Hambrick, D. C. and D'aveni, R. A. (1992). "Top team deterioration as part of the downward spiral of large corporate bankruptcies". Management Science, 38(10), pp. 1445-1466.

22. Hambrick, D. C., Geletkanycz, M. A. and Fredrickson, J. W. (1993). "Top executive commitment to the status quo: Some tests of its determinants". Strategic Management Journal, 14(6), pp. 401-418.

23.Hayes, R. H.; Hayes, R. H.; Wheelwright, S. C.; Wheelwright, S. and Clark, K. B. (1988. "Dynamic manufacturing: Creating the learning organization". Simon and Schuster.

24.Haque, M. S. (2004). "Governance based on partnership with NGOs: implications for development and empowerment in rural Bangladesh". International Review of Administrative Sciences, 70(2), pp. 271-290. 
25. Helfat, C. E. (2007). Stylized facts, empirical research and theory development in management. Strategic Organization, 5(2), 185-192.

26. Hunt, S. D., Chonko, L. B. and Wood, V. R. (1985). "Organizational commitment and marketing". Journal of marketing, 49(1), pp. 112-126.

27.Jugdev, K.; Mathur, G. and Fung, T. S. (2007). "Project management assets and their relationship with the project management capability of the firm". International Journal of Project Management, 25(6), pp. 560-568.

28.Kaaria, A. G.; Kamaara, M.; Nzulwa, J. and Ombui, K. (2018). "Moderating Effect of Top Management Commitment on Human Resource Information System and Organizational Performance in Commercial State Corporations in Kenya". Journal of Human Resource and Leadership, 3(3), pp. 4255.

29.Keegan, A. and Turner, J. R. (2002). "The management of innovation in project-based firms". Long range planning, 35(4), pp. 367-388.

30.Lengnick-Hall, C. A.; Beck, T. E. and Lengnick-Hall, M. L. (2011). "Developing a capacity for organizational resilience through strategic human resource management". Human Resource Management Review, 21(3), pp. 243-255.

31.Lieberman, M. B. and Dhawan, R. (2005). "Assessing the resource base of Japanese and US auto producers: A stochastic frontier production function approach". Management Science, 51(7), pp. 1060-1075.

32.Lin, C. T.; Chiu, H. and Chu, P. Y. (2006). "Agility index in the supply chain". International Journal of Production Economics, 100(2), pp. 285-299.

33.Long, C. (2000). "Measuring your strategic agility". Consulting to Management, 11(3), 25-28.

34.Marx, A. E. (1995). "Management commitment for successful suggestion systems". Work study, 44(3), pp. 16-18.

35.Michael, J. G. and Hambrick, D. C. (1992). "Diversification posture and top management team characteristics". Academy of Management journal, 35(1), pp. 9-37.

36. Miller, N. and Pazgal, A. (2002). "Relative performance as a strategic commitment mechanism". Managerial and Decision Economics, 23(2), pp. 51-68.

37.Narasimhan, R.; Swink, M. and Kim, S. (2006). "Disentangling leanness and agility: An empirical investigation". Journal of Operations Management, 24(5), pp. 440-457.

38.Ng, E. S. and Wyrick, C. R. (2011). "Motivational bases for managing diversity: A model of leadership commitment". Human Resource Management Review, 21(4), pp. 368-376.

39.Nidumolu, S. R. (1996). "A comparison of the structural contingency and risk-based perspectives on coordination in software-development projects". Journal of Management Information Systems, 13(2), pp. 77-113.

40.Nijssen, M. and Paauwe, J. (2012). "HRM in turbulent times: how to achieve organizational agility?". The International Journal of Human Resource Management, 23(16), pp. 3315-3335.

41.0'brien, D. (2012). "Developing strategy from the middle: subsidiary strategy and the role of the subsidiary general manager". Irish Journal of Management, 32(2), pp. 109-128.

42.Prabhu, V. B. and Robson, A. (2000). "Achieving service excellence-measuring the impact of leadership and senior management commitment". Managing Service Quality: An International Journal, 10(5), 307-317.

43.Prim, A.L., Laureano Paiva, E. and Kumar, M. (2019, July). "Interplaying Internal and External Mechanisms for the Operational Capabilities Development". In Academy of Management Proceedings (Vol. 2019, No. 1, p. 19273). Briarcliff Manor, NY 10510: Academy of Management.

44.Raelin, J. A. (1999). "The design of the action project in work-based learning". Human Resource Planning, 22(3), pp. 12-28.

45.Regnier, E. (2007). “Oil and energy price volatility”. Energy economics, 29(3), pp. 405-427.

46.Rhoades, L. and Eisenberger, R. (2002). "Perceived organizational support: a review of the literature". Journal of applied psychology, 87(4), pp. 698-714.

47.Sakthivel, P. B. (2007). "Top management commitment and overall engineering education excellence". The TQM Magazine, 19(3), pp. 259-273. 
48.Sambamurthy, V.; Bharadwaj, A. and Grover, V. (2003). "Shaping agility through digital options: Reconceptualizing the role of information technology in contemporary firms". MIS quarterly, 27(2), pp. 237-263.

49.Sadq, Z.M., Othman, B. and Khorsheed, R.K. (2019). "The impact of tourism marketing in enhancing competitive capabilities". African Journal of Hospitality, Tourism and Leisure, 8(5), pp.1-11.

50.Shafer, R. A.; Dyer, L.; Kilty, J.; Amos, J. and Ericksen, G. A. (2000). Crafting a human resource strategy to foster organizational agility: A case study. Human Resource Management: Published in Cooperation with the School of Business Administration, The University of Michigan and in alliance with the Society of Human Resources Management, 40(3), pp. 197-211.

51.Shah, A. M. (1996). "Strategy implementation: A study of critical factors". Indian journal of industrial relations, 32(1), pp. 42-55.

52.Sharifi, H. and Zhang, Z. (1999). "A methodology for achieving agility in manufacturing organizations: An introduction". International journal of production economics, 62(1-2), pp. 7-22.

53.Sharma, S. and Vredenburg, H. (1998). "Proactive corporate environmental strategy and the development of competitively valuable organizational capabilities". Strategic management journal, 19(8), pp. 729-753.

54.Sirmon, D. G. and Hitt, M. A. (2009). "Contingencies within dynamic managerial capabilities: Interdependent effects of resource investment and deployment on firm performance". Strategic management journal, 30(13), pp. 1375-1394.

55.Söderlund, J. (2005). “Developing project competence: empirical regularities in competitive project operations". International journal of innovation Management, 9(04), pp. 451-480.

56.Stekelenburg, J. V. (2012). "Exploring organizational agility and the added value of human resources: Creating organizational agility by using individual competencies and organizational practices". Unpublished Master's Thesis, Tilburg University, Tilburg, Netherlands.

57.Teece, D.; Peteraf, M. and Leih, S. (2016). "Dynamic capabilities and organizational agility: Risk, uncertainty, and strategy in the innovation economy". California Management Review, 58(4), pp. 13-35.

58.Teece, D. J.; Pisano, G. and Shuen, A. (1997). "Dynamic capabilities and strategic management". Strategic management journal, 18(7), pp. 509-533.

59.Thao, T. P. (2012). "Enterprise systems and organizational agility: Developing and exploring a Causal Model." Doctor of Philosophy, School of Business Information Technology and Logistics Business College, RMIT University.

60.De Toni, A. and Tonchia, S. (2003). "Strategic planning and firms' competencies: Traditional approaches and new perspectives". International Journal of Operations \& Production Management, 23(9), pp. 947-976.

61.Van Der Vegt, G. S.; Essens, P.; Wahlström, M. and George, G. (2015). "Managing risk and resilience". Academy of Management Journal, 58(4), pp. 971-980.

62.Virany, B., Tushman, M. L. and Romanelli, E. (1992). "Executive succession and organization outcomes in turbulent environments: An organization learning approach". Organization Science, 3(1), pp. 72-91.

63.Yousif, M.; Pessi, K.; Lundin, J. and Svensson, L. (2016, June). "It Agility Research Review: Thematic Analysis and Categorization of literature". In PACIS (p. 205).

64.Zahra, S. A. and George, G. (2002). "The net-enabled business innovation cycle and the evolution of dynamic capabilities". Information systems research, 13(2), pp. 147-150.

65.Zott, C. (2003). "Dynamic capabilities and the emergence of intraindustry differential firm performance: insights from a simulation study". Strategic management journal, 24(2), pp. 97-125. 